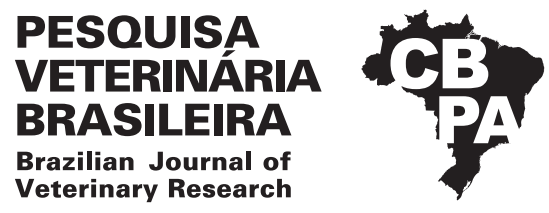

Pesq. Vet. Bras. 39(7):516-522, July 2019 DOI: $10.1590 / 1678-5150-P V B-5892$

ISSN 0100-736X (Print)

ISSN 1678-5150 (Online)

\title{
Oral lesions and retroviruses in shelter cats $^{1}$
}

\author{
Ana Paula da Silva²* (D), Mariana Flores², Renata Mazaro², Flavia da Luz², \\ Marcia Silva $^{2}$ and Rafael A. Fighera ${ }^{2}$
}

\begin{abstract}
Silva A.P., Flores M., Mazaro R., Luz F., Silva M. \& Fighera R.A. 2019. Oral lesions and retroviruses in shelter cats. Pesquisa Veterinária Brasileira 39(7):516-522. Hospital Veterinário Universitário, Universidade Federal de Santa Maria, Avenida Roraima 1000, Camobi, Santa Maria, RS 97105-900, Brazil. E-mail: apsvet@hotmail.com

Oral lesions are common problems in feline medicine worldwide, and may be associated with different causes, such as infectious agents. There are only a few studies reporting the chief oral diseases and the results for retrovirus tests in shelter cats in Brazil, especially in the South region. This study aimed to identify the main inflammatory oral lesions in shelter cats and verify the test results for feline immunodeficiency virus (FIV) and feline leukemia virus (FeLV) infections. Forty-three felines from private shelters in the central region of Rio Grande do Sul state (RS) that presented clinically evident oral lesions, regardless of age, breed, sex, and neuter status, were used in this survey. Serological tests for FIV and FeLV were performed in all cats, and data regarding the rearing system were collected. Sixteen cats (37.2\%) were reared in a free system, whereas $27(62.8 \%)$ were kept under a restrict system. Of the 43 cats with oral lesions, $29(67.44 \%)$ presented only one type of lesion, characterized as periodontitis $(n=22,51.16 \%)$, followed by gingivitis $(n=6,13.95 \%)$, and stomatitis $(\mathrm{n}=1,2.32 \%)$. Concomitant stomatitis and periodontitis were found in the 14 remaining cats $(100 \%)$. With respect to the test results for retrovirus infections, nine $(20.93 \%)$ of the 43 felines were positive for FIV alone. Co-infection with both viruses was observed in seven cats (16.28\%). No cat was seropositive for FeLV valone. None of the six cats that presented gingivitis was positive for FIV and FeLV; one cat with stomatitis was positive for FIV and FeLV; of the 22 cats with periodontitis, six (27.27\%) were FIV positive and two $(9.09 \%)$ were FIV/FeLV positive; and of the 14 cats that presented stomatitis and periodontitis, three (21.43\%) were FIV positive and four (28.57\%) were FIV/FeLV positive. As for diagnosis, 28 cats (65.1\%) presented solely periodontal disease (PD), one cat (2.32\%) had feline chronic gingivostomatitis (FCG) alone, and 14 (32.5\%) had both PD and FCG. The results obtained show that the main oral lesions found in shelter cats in the central region of RS were gingivitis, stomatitis, and periodontitis. Periodontitis, in association or not with stomatitis, was the most frequently observed oral cavity lesion in FIV-and/or FeLV-positive cats. Other factors may contribute to installation of inflammatory oral diseases in shelter cats because most cats with oral cavity lesions tested negative for retrovirus infections.
\end{abstract}

INDEX TERMS: Oral lesions, retroviruses, shelter cats, feline medicine, periodontal disease, gingivostomatitis, immunodeficiency, leukemia, clinics.

\footnotetext{
${ }^{1}$ Received on October 31, 2018.

Accepted for publication on February 12, 2019.

${ }^{2}$ Graduate Studies Program in Veterinary Medicine, Hospital Veterinário Universitário, Universidade Federal de Santa Maria (UFSM), Av. Roraima 1000, Camobi, Santa Maria, RS 97105-900, Brazil. E-mails: apsvet@hotmail.com, marianamflores@yahoo.com.br, renatamazaro92@gmail.com,flavinha.sl@ hotmail.com, marccias@hotmail.com, anemiaveterinaria@yahoo.com.br; *Corresponding author: apsvet@hotmail.com
}

RESUMO.- [Afecções orais e retroviroses em gatos de abrigo.] As afecções orais são problemas comuns em medicina felina em diferentes locais do mundo e podem estar relacionadas a diferentes causas, como agentes infecciosos. Poucos estudos foram encontrados no Brasil sobre o levantamento das principais doenças orais e dos resultados de testes para retrovírus em gatos de abrigos, principalmente na região Sul. Diante disso, o objetivo deste artigo foi identificar as principais afecções orais inflamatórias em gatos de 
abrigos e verificar os resultados dos testes para o vírus da imunodeficiência felina (FIV) e o vírus da leucemia felina (FeLV). Foram incluídos 43 felinos provenientes de abrigos privados localizados na região central do Rio Grande do Sul (RS) que apresentavam lesões orais clinicamente evidentes, independente de idade, raça, gênero e estado reprodutivo. Em todos os gatos foram realizados testes sorológicos para FIV e FeLV e obtidas informações referentes ao sistema de criação. Em 16 gatos (37,2\%), o sistema de criação era livre, enquanto em $27(62,8 \%)$ era restrito. Dos 43 gatos com lesões orais, em $29(67,44 \%)$ foi verificado somente um tipo de lesão, caracterizado como periodontite $(n=22,51,16 \%)$, seguido de gengivite $(n=6,13,95 \%)$ e estomatite $(n=1,2,32 \%)$. Lesões concomitantes de estomatite e periodontite foram encontradas nos 14 gatos $(100 \%)$ restantes. Quanto aos resultados dos testes para retrovírus, nove $(20,93 \%)$ dos 43 felinos testados, foram positivos somente para FIV. Em sete gatos $(16,28 \%)$ foi observada coinfecção pelos dois vírus. Em nenhum gato foi observado soropositividade somente para FeLV. Dos seis gatos com gengivite, nenhum foi positivo para FIV e FeLV; um gato com estomatite foi positivo para FIV e FeLV; dos 22 gatos com periodontite, seis $(27,27 \%)$ foram FIV positivos e dois (9,09\%) FIV/FeLV positivos; e dos 14 com estomatite e periodontite, três $(21,43 \%)$ foram FIV positivos e quatro $(28,57 \%) \mathrm{FIV} / \mathrm{FeLV}$ positivos. Quanto ao diagnóstico, em 28 gatos $(65,1 \%)$ foi observada somente doença periodontal (DP), em um $(2,32 \%)$ somente gengivoestomatite crônica felina (GECF) e em 14 gatos (32,5\%) DP e GECF. Diante dos resultados obtidos, pode-se concluir que as principais lesões orais encontradas em gatos de abrigos da região central do RS foram gengivite, estomatite e periodontite; a periodontite associada ou não a estomatite foi a lesão oral mais frequente nos gatos positivos para FIV e/ou FeLV. Acredita-se que outros fatores possam contribuir na instalação de doenças orais em gatos de abrigos, já que houve predomínio de gatos com resultados negativos nos testes para os retrovírus.

TERMOS DE INDEXAÇÃO: Afecções orais, retroviroses, gatos de abrigo, medicina felina, doença periodontal, gengivoestomatite, imunodeficiência, leucemia, clínica.

\section{INTRODUCTION}

Inflammatory oral disease in cats is a complex and multifactorial condition consisting primarily of local or widespread inflammation in the oral cavity (Kornya et al. 2014). The main oral diseases observed in felines are periodontal disease (PD) (Clarke \& Cameron 1998, Perry \& Tutt 2015), which corresponds to $13.9 \%$ of all diagnoses for this species (O’Neill et al. 2014), and feline chronic gingivostomatitis (FCG), which accounts for approximately $72 \%$ of the odontological diagnoses (Frost \& Williams 1986).

PD is mainly caused by Gram-positive aerobic bacteria, although other risk factors are associated with the prevalence and severity of periodontal lesions (Logan 2006, Perry \& Tutt 2015). Other causes acknowledged in the PD and FCG etiology include dental calculus deposits, an unbalanced diet -including lack of dry foods (Studer \& Stapley 1973, Watson 1994, Clarke \& Cameron 1998, Logan 2006), and immunological factors (Tenorio et al. 1991).

FCG is characterized by persistent, usually severe inflammation of the gingiva and oral mucosa presenting ulcerative and/or proliferative lesions, especially in the palatoglossal arch region (Lyon 2005). FCG may be considered as multifactorial, although it is likely that infectious agents are involved (Mallonee et al. 1988, Love \& Zuber 1987, Knowles et al. 1989, Tenorio et al. 1991, Lyon 2005).

Upon diagnosing oral cavity lesions in cats, the possibility of underlying systemic diseases should be considered. It is believed that oral cavity lesions occur in cats infected with the feline immunodeficiency virus (FIV) or feline leukemia virus (FeLV) due to their systemic immunosuppressing effect, which hinders the animals' ability to fight the pathogens. Oral cavity lesions are among the different clinical manifestations of retrovirus infections, and are characterized by several degrees of gingivitis, stomatitis, and periodontitis (Arzi et al. 2008).

FIV and FeLV belong to the family Retroviridae. They can cause insidious infections specific of domestic felines, and are usually disseminated in cat populations (Levy et al. 2008, Hartmann 2011). FIV is a retrovirus of the genus Lentivirus, which is transmitted primarily in saliva through the bite wounds (Hosie et al. 2009). FeLV is a Gammaretrovirus that is also primarily transmitted via saliva (Lutz et al. 2009).

Prevalence of FIV and FeLV infections varies widely according to the characteristics of the populations evaluated (Levy et al. 2006). In the United States, the prevalence of both infections is approximately 2\% in healthy cats and 30\% in high-risk or unhealthy felines (Levy et al. 2006).

In Brazil, research on the occurrence of FIV and FeLV infections in cats from different regions (Northeast, Central-West, South, and Southeast) and facilities (veterinary hospitals and clinics, shelters, or private homes) showed prevalence figures varying from below 2.0 to $37.5 \%$ and from 8.0 to $63.0 \%$, for FIV and FeLV, respectively (Teixeira et al. 2007, Meinerz et al. 2010, Santos et al. 2013, Almeida et al. 2016, Barros et al. 2017, Poffo et al. 2017). However, none of these studies have identified the occurrence of the chief oral lesions in the populations tested for retroviruses.

Therefore, due to the relevance of this topic and the absence of data on the main oral cavity diseases and test results for retrovirus infection in shelter cats in the South region of Brazil, this study aimed to identify the main oral lesions and verify the test results in a feline population in the central region of Rio Grande do Sul state.

\section{MATERIALS AND METHODS}

The study sample was composed of forty-three felines from three private shelters located in the central region of Rio Grande do Sul state, Brazil, presenting clinically evident oral cavity lesions regardless of age, breed, sex, and neuter status, and with no vaccination record. Inclusion criteria for oral evaluation were based on the owners observation of changes in the animals' behavior during feeding, such as difficulty grasping, dysphagia and/or sialorrhea.

Patients were authorized to participate in the study by the owner-manager of each shelter, and all procedures were approved by the Ethics Committee on Animal Use (CEUA) of Universidade Federal de Santa Maria (UFSM) under protocol no. 4659251017/2017.

The animals' oral cavity was inspected under general dissociative anesthesia, prepared with an association of ketamine hydrochloride $10 \%(8 \mathrm{mg} / \mathrm{kg})^{-1}$ and xylazine hydrochloride $2 \%\left(1 \mathrm{mg} / \mathrm{kg}^{-1}\right)$, both administered through deep intramuscular route.

According to the gross findings, oral lesions were classified as follows: 1) gingivitis (inflammation of the gingiva alone); 
2) periodontitis (inflammation of the periodontium); 3) stomatitis (inflammation of the mucosa lining the caudal oral cavity lateral to the palatoglossal arch, extending rostrally to the gingiva, the alveolar, oral, labial and sublingual mucosae and, occasionally, to the ventral and dorsal surfaces of the tongue, including lesions compatible with FCG (Gawor et al. 2006, Reiter \& Soltero-Rivera 2017). Each cat was diagnosed with PD and/or gingivostomatitis (GS) according to the lesions observed (Table 1). Non-inflammatory oral lesions, such as dental fractures and absence of teeth, were not included in this study.

Blood samples ( $3 \mathrm{~mL}$ ) were collected from the jugular vein following tricotomy and antisepsis and stored in tubes containing EDTA and serum separation tubes for further detection of anti-FIV antibodies

Table 1. Gender, reproductive status, age, type of oral lesion, diagnosis, and test results for retrovirus infections of the 43 felines from shelters in the central region of Rio Grande do Sul state, Brazil

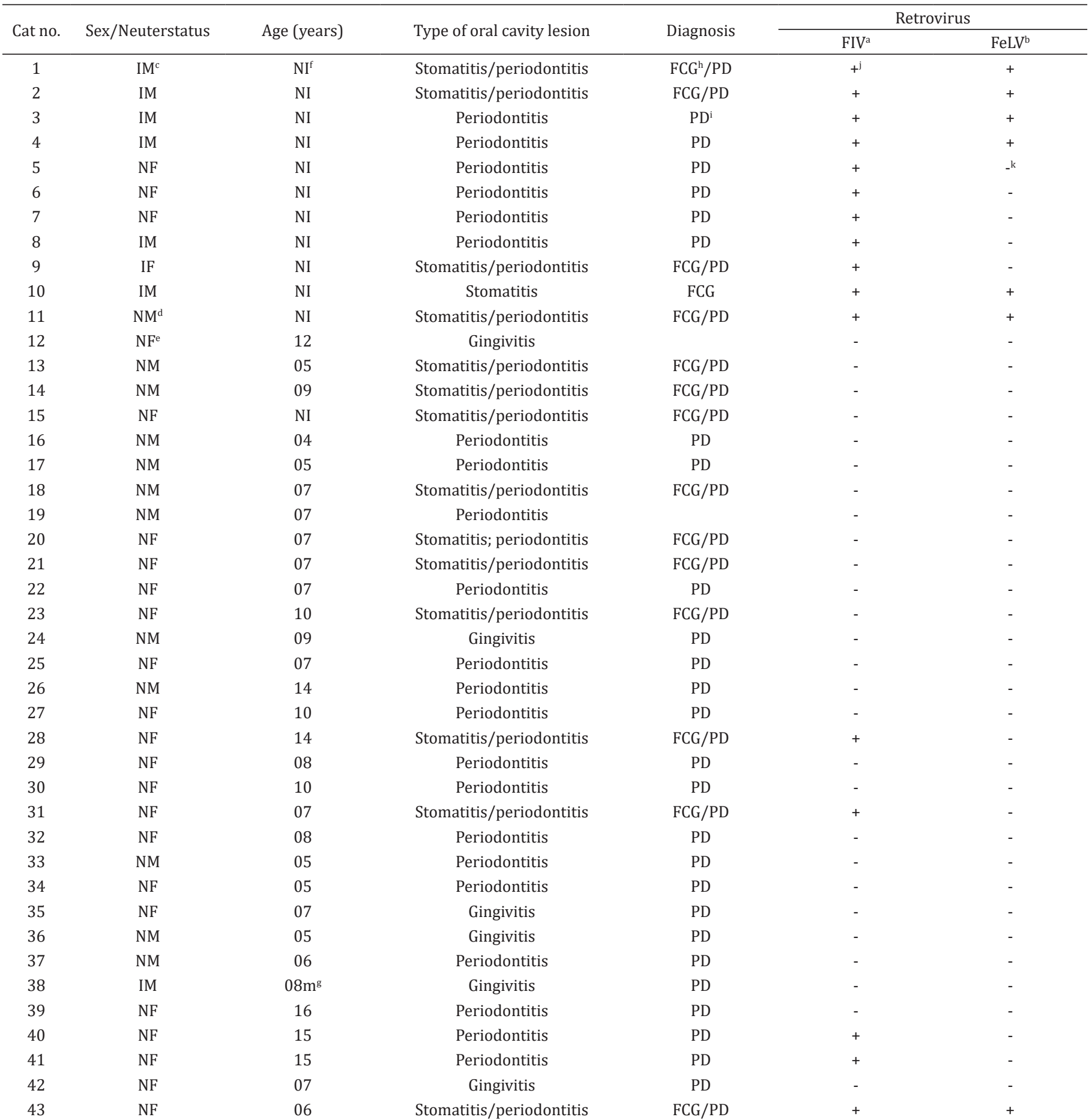

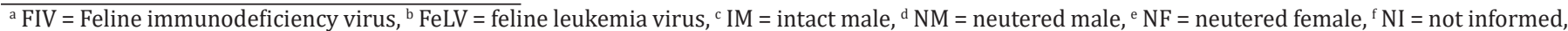
${ }^{\mathrm{g}} \mathrm{m}=$ months, ${ }^{\mathrm{h}} \mathrm{FCG}=$ feline chronic gingivostomatitis, $\mathrm{PD}=$ periodontal disease, ${ }^{\mathrm{j}}(+)=$ positive, $^{\mathrm{k}}(-)=$ negative. 
and FeLV antigens (SNAP Combo FeLV/FIV; IDEXX Laboratories). Sensitivity and specificity test values were 100 and $98.6 \%$ for the FeLV antigen and 99.2 and $100 \%$ for the anti-FIV antibody, respectively (Burling et al. 2017). No confirmatory laboratory tests were performed.

The cats were identified in individual records containing information on age, sex, breed, neuter status, rearing system, findings of the oral examination, and test results for retrovirus infections.

As for the age variable, the cats were classified into the following groups: kittens ( $\leq 1$ year), adults ( $>1$ and $\leq 9$ years), and elderly ( $>9$ years) (Martins 2016). Regarding neuter status, the animals were classified as sexually intact or neutered. Unknown ages were recorded as not informed (Table 1).

With respect to the rearing system, the cats were either freely raised with access to the streets or restricted to the shelter's facilities at all times.

Information regarding gender, neuter status, age, oral cavity lesions, diagnoses, and test results for FIV and FeLV infections are shown in percentage (\%).

\section{RESULTS}

Three shelters located in three different municipalities in the central region of Rio Grande do Sul state, with a total population of 92 felines, were evaluated. Of these, 43 cats with oral cavity lesions were included in the study distributed as follows: 11 (100\%) animals from Shelter 1, 27 (36.49\%) from Shelter 2, and five (71.42\%) from Shelter 3.

Of the 43 cats that composed the study sample, the age of $31(72.09 \%)$ animals was informed by the owners: one $(3.22 \%)$ was a kitten, 21 (67.74\%) were adults, and nine (29.03\%) were elderly. Their age varied from eight months to 16 years (median $=9$ ). The owners were unable to inform the age of 12 cats (27.91\%) (Table 1$)$.

As for gender, $24 / 43$ (55.81\%) were females and 19/43 $(44.19 \%)$ were males. Regarding neuter status, 8/43 cats (18.60\%) were sexually intact (one female and seven males) and 35/43 (81.40\%) were neutered (12 males and 23 females). All 43 felines evaluated (100\%) were mixed breed (MB).

Among the 43 cats with clinically evident oral cavity lesions, $29(67.44 \%)$ presented a single type of lesion, namely, gingivitis, six (13.95\%) (Fig.1);stomatitis, one $(2.32 \%)$ (Fig.2);periodontitis, 22 (51.16\%) (Fig.3). Dual oral infection, stomatitis and periodontitis, was observed in the $14(32.56 \%)$ remaining cats $(100 \%)$ (Table 1$)$.

With respect to the test results for retrovirus infections, nine $(20.93 \%)$ out of the 43 felines tested positive solely for FIV and none presented solely FeLV infection. Concomitant infection (co-infection) with FIV and FeLV was observed in seven cats $(16.28 \%)$ (Table 2$)$. Out of the 27 retrovirus-seronegative



Fig.1. Mild gingival hyperemia (gingivitis) in shelter cat from the central region of Rio Grande do Sul state, Brazil.

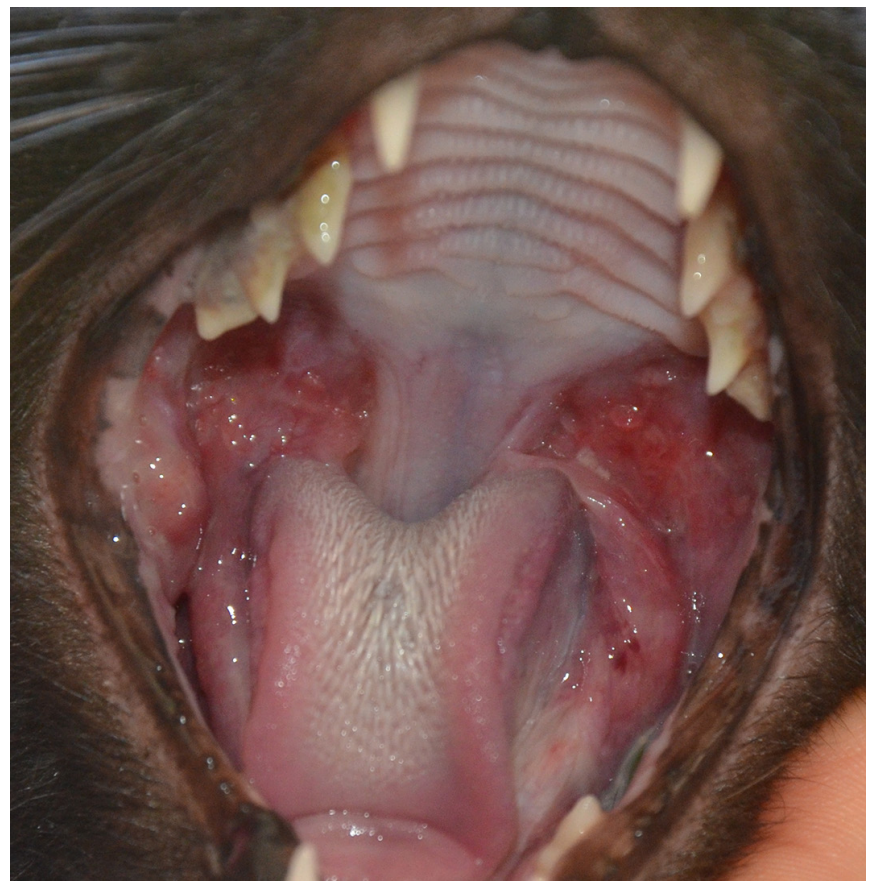

Fig.2. Bilateral ulceroproliferative lesions in shelter cat from the central region of Rio Grande do Sul state, Brazil, in the oral caudal and lateral mucosa of the palatoglossal arches indicative of caudal stomatitis (gingivostomatitis) and presence of dental calculus in the maxillary teeth (periodontitis).

Table 2. Types of oral lesion and test results for retrovirus infections of the $\mathbf{4 3}$ felines from shelters in the central region of Rio Grande do Sul state, Brazil

\begin{tabular}{|c|c|c|c|c|c|}
\hline Type of oral lesion & Cat no. ${ }^{a}$ & $\operatorname{FIV}^{b}(+)^{c}$ & FIV $(-)^{d}$ & $\mathrm{FIV} / \mathrm{FeLV}^{\mathrm{e}}(+)$ & FIV/FeLV (-) \\
\hline Gingivitis & $06(13.96 \%)$ & -- & $06(22.22 \%)$ & -- & $06(22.22 \%)$ \\
\hline Stomatitis & $01(2.32 \%)$ & - & - & $01(14.28 \%)$ & - \\
\hline Periodontitis & $22(51.16 \%)$ & $06(66.66 \%)$ & $14(51.85 \%)$ & $02(28.57 \%)$ & $14(51.85 \%)$ \\
\hline Stomatitis/periodontitis & $14(32.56 \%)$ & $03(33.34 \%)$ & $07(25.92 \%)$ & $04(57.14 \%)$ & $07(25.92 \%)$ \\
\hline TOTAL & $43(100 \%)$ & $09(20.93 \%)$ & 27 (62.79\%) & 07 (16.27\%) & $27(62.79 \%)$ \\
\hline
\end{tabular}

${ }^{a}$ None of the cats tested positive solely for FeLV, ${ }^{\mathrm{b}}$ FIV $=$ feline immunodeficiency virus, ${ }^{\mathrm{c}}(+)=$ positive, ${ }^{\mathrm{d}}(-)=$ negative, ${ }^{\mathrm{e}}$ FeLV $=$ feline leukemia virus. 


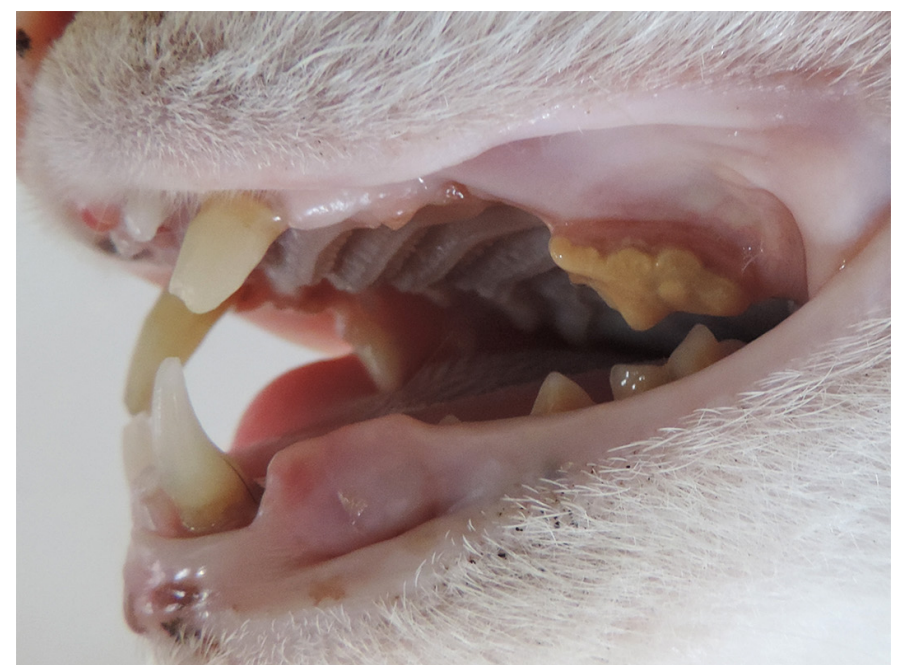

Fig.3. Severe inflammation of the gingiva in shelter cat from the central region of Rio Grande do Sul state, Brazil, with gingival retraction and dental calculus deposition, evident in the 4 th left maxillary pre-molar, which characterizes periodontal disease (periodontitis).

cats, six (22.22\%) presented gingivitis; one $(3.70 \%)$, stomatitis; 14 (51.85\%), periodontitis; and seven (25.92\%), stomatitis/periodontitis (Table 1).

With regard to association of oral cavity lesions with FIV and/or FeLV seropositivity, of the six cats with gingivitis, none were FIV- or FeLV-positive and one animal with stomatitis was FIV and FeLV-positive. Of the 22 felines with periodontitis, six were FIV-positive and two were FIV- and FeLV-positive. Of the 14 cats with stomatitis and periodontitis, three were FIV-positive and four were FIV- and FeLV-positive (Table 2).

PD alone was observed in 28 cats (65.1\%); GS alone was found in one animal (2.32\%), and DP and GS was verified in 14 felines (32.5\%) (Table 1).

As for the rearing system, 16 cats (59.25\%) lived freely, whereas 27 (40.75\%) were raised restricted to the shelters.

\section{DISCUSSION}

Inclusion criteria for oral evaluation were based on the owners' observation of changes in the animals' behavior during feeding, such as difficulty grasping, dysphagia and/or sialorrhea altogether, these symptoms were observed in 43 cats. Although the study initially proposed to perform oral examination in all cats, this did not occur in the entire population (92 cats) because of difficulty to seize them and lack of authorization on the part of owners.

The cats included in this study were aged eight months to 16 years (median $=9$ ); owners were unable to inform the age of 12 cats (27.91\%) (Table 2 ). In a study conducted by Tenorio et al. (1991), which assessed chronic oral cavity infections in cats and their association with calicivirus, FIV, and FeLV, the animals' age varied from one to 18 years, and FeLV and calicivirus positivity was observed in young animals, whereas FIV was observed in adults. Kornya et al. (2014), in determining the association of test results positive for retrovirus infections with occurrence of oral cavity lesions in cats, observed that increased age was associated with higher prevalence of inflammatory oral disease in retrovirus-negative cats. Findings of the present study do not allow association between age range and test results for retrovirus infections, as the age of most of the FIV- and FeLV-positive cats was unknown. However, all FIV-positive cats were adults or elderly, and the only FeLV-positive cat whose age was known was an adult (Table 1).

FIV is mainly transmitted through biting, where the virus present in the saliva of an infected cat is inoculated into the blood stream of a healthy cat (Sellon \& Hartmann 2012, Hagiwara et al. 2016). Adult sexually intact males with access to the streets constitute the main group at risk of infection (Levy et al. 2006) because of their aggressive behavior (Hosie et al. 2009, Grace 2011). In this study, 14 (87.50\%) of 16 cats $(37.20 \%)$ freely reared were FIV-positive. Of these, six (42.85\%) were sexually intact males, one $(7.14 \%)$ was a neutered male, and three $(21.42 \%)$ were neutered females. Only two (7.41\%) neutered females reared restricted to shelter $(n=27)$ tested positive for FIV. The neutered females with access to the street may have become infected because of their aggressive behavior or during mating, following a bite from an infected male, prior to their spaying.

The owners' lifestyle, hygiene measures, and socioeconomic profile may have influenced the prevalence of retroviral infections. In this study, a shelter with 11 cats had five $(45.45 \%)$ FIV-positive animals and six (54.55\%) FIV- and FeLV-positive animals. Another shelter with five cats evaluated in this study had two (40\%) FIV-positive animals and one (20\%) FIV- and FeLV-positive animal. These shelters reared cats freely, with access to the street, and the owners' socioeconomic status was apparently low. In contrast, among the felines reared restricted to the shelter $(n=27)$, only two cats were FIV-positive. Due to the socioeconomic status of their owners, they lived under more appropriate hygiene and handling conditions compared with those in the two other shelters - most of the animals were even submitted to deworming schedules.

Cats infected with FIV present different clinical symptoms, such as chronic rhinitis, lymphadenopathy, weight loss, glomerulonephritis (Hosie et al. 2009), and chronic gingivostomatitis, which affects more than $50 \%$ of FIV-positive cats (Hosie et al. 2009, Hartmann 2011). Another study conducted with 826 cats naturally infected with FIV reported that the most prevalent syndromes associated with seropositive cats were chronic gingivostomatitis, neoplasm, ocular inflammation, and anemia (Levy 2000). In the present study, of the 15 cats with FCG, two (13.33\%) were FIV-positive and five (33.33\%) were FIV- and FeLV-positive (co-infection).

PD is characterized by inflammation of the periodontal tissues. Initially, it affects the gingiva (gingivitis) and then other tissues, including the cementum-periodontal ligament and the alveolar bone (periodontitis) (Logan 2006, Perry \& Tutt 2015). FCG is a chronic oral disease characterized by ulcerative and/or proliferative lesions beginning in the mucogingival junction (Perry \& Tutt 2015). In this study, of the 43 cats with oral lesions, 28 (65.1\%) presented solely PD, one $(2.32 \%)$ had solely FCG, and 14 (32.5\%) showed PD and FCG. It is also worth noting that of the 15 cats with gingivostomatitis, 14 (93.3\%) presented concomitant periodontal disease, which reiterates the hypothesis of PD being a cause of FCG (Gioso 2003, Winer et al. 2016). 
Progression of PD is determined by the microorganism's virulence combined with the host's immunological response (Nisengard et al. 2006). Individuals with compromised immunological response present more severe periodontal diseases (Wiggs \& Lopprise 1997). In humans, the immunodeficiency virus, diabetes, and stress are considered risk factors for periodontitis. In cats, it is believed that oral cavity lesions occur in individuals infected with FIV and/or FeLV because of the systemic immunosuppressing effect of these viruses, which hinders resistance to pathogens (Arzi et al. 2008). In this study, of the 42 cats with PD (Table 1), 12 (28.57\%) were FIV-positive and six were FIV- and FeLV-positive (14.28\%), which probably contributed to the increased severity of this lesion in seropositive cats.

The impossibility of evaluating all of the 92 cats reared in the three assessed shelters, which precluded the analysis of the retrovirus tests in cats that may not have presented oral lesions, as well as the non-identification of the age of 11 FIV- and/or FeLV-positive cats, were limiting factors of this study, which hindered association of the oral cavity lesions and test results for retrovirus infections with the animals' age range. Additionally, not performing confirmatory tests and, consequently, the possibility of false positive results, also limited the scope of this study, as mentioned by Levy et al. (2006) and Kornya et al. (2014).

This research observed that the six cats with gingivitis were retrovirus-seronegative, which suggests that this type of lesion may be related to other causes (Perry \& Tutt 2015, Möstl et al. 2013). Of the 22 cats (51.16\%) presenting periodontitis, six were seropositive for FIV and two for FIV and FeLV. Of the 14 felines (32.56\%) presenting stomatitis and periodontitis, three were seropositive for FIV and four for FIV and FeLV (Table 2). None of the cats presenting oral cavity lesions were solely FeLV-positive. Predominance of FIV-positive cats with periodontitis, associated or not with stomatitis, coincides with the findings reported by Kornya et al. (2014), who found association of FIV-positive cats with this type of lesion. Also noteworthy is the significant rate of co-infection observed in the present study, as seven (43.75\%) of 16 cats with retroviral infection were both FIV- and FeLV-positive. Conversely, Kornya et al. (2014), upon determining association of oral health with FIV and FeLV seropositivity, considered this type of condition to be uncommon.

Association of chronic oral lesions with retroviruses in felines remains controversial (Knowles et al. 1989, Tenorio et al. 1991, Quimby et al. 2008, Kornya et al. 2014, Rolim et al. 2016). Although this study did not associate oral lesions with the test results for retrovirus infections, it was verified that of 43 cats with oral cavity lesions, nine were FIV-positive and seven were both FIV- and FeLV-positive. Therefore, it is believed that retrovirus seropositivity may have contributed to and increased the severity of oral cavity lesions in these 16 cats, as the 27 (62.79\%) remaining felines were seronegative and presented the same types of oral cavity lesions. Thus, even if association had been found, other factors such as overcrowding, inadequate sanitary conditions, dietary imbalance, and stress (Pedersen \& Wastlhuber 1991, Foley 2012, Möstl et al. 2013) were also observed in the study population and must be considered in the occurrence of oral cavity lesions in shelter cats.

\section{CONCLUSIONS}

The results obtained show that the main oral cavity lesions found in shelter cats in the central region of Rio Grande do Sul state were gingivitis, stomatitis, and periodontitis.

Periodontitis, associated or not with stomatitis, was the most frequently observed oral cavity lesion in the FIV- and/or FeLV-positive cats.

Other factors may contribute to the occurrence of inflammatory oral disease in shelter cats because most cats with oral cavity lesions tested negative for retrovirus infections.

Conflict of interest statement.- The authors have no competing interests.

\section{REFERENCES}

Almeida N.R., Soares L.C. \& Wardini A.B. 2016. Alterações clínicas e hematológicas em gatos domésticos naturalmente infectados pelo Vírus da Leucemia Felina (FeLV). Revta Saúde 7(1):27-32. <http://dx.doi. org/10.21727/rs.v7i1.998>

Arzi B., Anderson J.G. \& Verstraete F.J.M. 2008. Oral manifestations of systemic disorders in dogs and cats. J. Vet. Clin. Sci. 1(4):112-124.

Barros V.R., Bezerra J.A.B., Bochnakian M.S., Paula V.V. \& Filgueira K.D. 2017. Epidemiology of feline immunodeficiency virus and feline leukemia virus in a veterinary teaching hospital. Revta Bras. Hig. Sanidade Anim. 11(2):151160. <http://dx.doi.org/10.5935/1981-2965.20170016>

Burling A.N., Levy J.K., Scott H.M., Crandall M.M., Tucker S.J., Wood E.G. \& Foster J.D. 2017. Seroprevalences of feline leukemia virus and feline immunodeficiency virus infection in cats in the United States and Canada and risk factors for seropositivity. J. Am. Vet. Med. Assoc. 251(2):187-194. <http://dx.doi.org/10.2460/javma.251.2.187> <PMid:28671491>

Clarke D.E. \& Cameron A. 1998. Relationship between diet, dental calculus and periodontal disease in domestic and feral cats in Australia. Aust. Vet. J. 76(10):690-693. <http://dx.doi.org/10.1111/j.1751-0813.1998.tb12284. $\mathrm{x}><$ PMid:9830570>

Foley J. 2012. Prevention and management of infectious diseases in multiplecat enviroments, p.1130-1136. In: Greene C.E. (Ed.), Infectious Diseases of the Dog and Cat. 4th ed. Elsevier, St Louis.

Frost P. \& Williams C.A. 1986. Feline dental disease. Vet. Clin. N. Am., Small Anim. Pract. 16(5):851-873. <http://dx.doi.org/10.1016/S01955616(86)50305-3> <PMid:3490037>

Gawor J.P., Reiter A.M., Jodkowska K., Kurski G., Wojtacki M.P. \& Kurek A. 2006. Influence of diet on oral health in cats and dogs. J. Nutrition 136(Suppl.7):2021s-2023s. <http://dx.doi.org/10.1093/jn/136.7.2021S> <PMid:16772485>

Gioso M.A. 2003. Odontologia Veterinária para o Clínico de Pequenos Animais. 5a ed. MinhaEditora, Manole, São Paulo. 202p.

Grace S.F. 2011. Feline immunodeficiency virus infection, p.179-180. In: Norsworthy G.D., Grace S.F., Crystal M.A. \& Tilley L.P. (Eds), The Feline Patient. 4th ed. Blackwell, Ames.

Hagiwara M.K., Reche A.J.R. \& Teixeira B.M. 2016. Retroviroses dos felinos: síndrome da imunodeficiência dos felinos, p.836-843. In: Megid J., Ribeiro M.G. \& Paes A.C. (Eds), Doenças Infecciosas em Animais de Produção e de Companhia. Roca, Rio de Janeiro.

Hartmann K. 2011. Clinical aspects of feline immunodeficiency and feline leukemia virus infection. Vet. Immunol. Immunopathol. 143(3/4):190-201. <http://dx.doi.org/10.1016/j.vetimm.2011.06.003><PMid:21807418>

Hosie M.J., Addie D., Belák S., Boucraut-Baralon C., Egberink H., Frymus T., Gruffydd-Jones T., Hartmann K., Lloret A., Lutz H., Marsilio F., Pennisi M.G., Radford A.D., Thiry E., Truyen U. \& Horzinek M.C. 2009. Feline immunodeficiency ABCD guidelines on prevention and management. J. Feline 
Med. Surg. 11(7):575-584.<http://dx.doi.org/10.1016/j.jfms.2009.05.006> <PMid:19481037>

Knowles J.O., Gaskell R.M., Gaskell C.J., Harvey C.E. \& Lutz H. 1989. Prevalence of feline calicivirus, feline leukaemia virus and antibodies to FIV in cats with chronic stomatitis. Vet. Rec. 124(13):336-338. <http://dx.doi.org/10.1136/ vr.124.13.336><PMid:2541529>

Kornya M.R., Little S.E., Scherk M.A., Sears W.C. \& Bienzle D. 2014. Association between oral health status and retrovirus test results in cats. J. Am. Vet. Med. Assoc. 245(8):916-922.<http://dx.doi.org/10.2460/javma.245.8.916> $<$ PMid:25285933>

Levy J.K. 2000. Feline immunodeficiency virus update, p.284-288. In: Bonagura J. (Ed.), Kirk's Current Veterinary Therapy XIII: small animal practice. Vol.13. W.B. Saunders, Philadelphia.

Levy J.K., Scott H.M., Lachtara J.L. \& Crawford P.C. 2006. Seroprevalence of feline leukemia virus and feline immunodeficiency virus infection among cats in North America and risk factors for seropositivity. J. Am. Vet. Med. Assoc. 228(3):371-376. <http://dx.doi.org/10.2460/javma.228.3.371> <PMid:16448357>

Levy J., Crawford C., Hartmann K., Hofmann-Lehmann R., Little S., Sundahl E. \& Thayer V. 2008. American Association of Feline Practitioners' feline retrovirus management guidelines. J. Feline Med. Surg. 10(3):300-316. <http://dx.doi.org/10.1016/j.jfms.2008.03.002> <PMid:18455463>

Logan E.I. 2006. Dietary influences on Periodontal Health in dogs and cats. Vet. Clin. N. Am., Small Anim. Pract. 36(6):1385-1401. <http://dx.doi. org/10.1016/j.cvsm.2006.09.002><PMid:17085242>

Love D.N. \& Zuber R.M. 1987. Feline calicivirus associated with pyrexia, profound anorexia and oral and perianal ulceration in a cat. Aust. Vet. Pract. 17(1):136-137.

Lutz H., Addie D., Belák S., Boucraut-Baralon C., Egberink H., Frymus T., Gruffydd-Jones T., Hartmann K., Hosie M.J., Lloret A., Marsilio F., Pennisi M.G., Radford A.D., Thiry E., Truyen U. \& Horzinek M.C. 2009. Feline leukaemia. ABCD guidelines on prevention and management. J. Feline Med. Surg. 11(7):565-574. <http://dx.doi.org/10.1016/j.jfms.2009.05.005> <PMid:19481036>

Lyon K.F. 2005. Gingivostomatitis. Vet. Clin. N. Am., Small Anim. Pract. 35(4):891-911. <http://dx.doi.org/10.1016/j.cvsm.2005.02.001>

Mallonee D.H., Harvey C.E., Venner M. \& Hammond B.F. 1988. Bacteriology of periodontal disease in the cat. Arch. Oral Biol. 33(9):677-683. <http:// dx.doi.org/10.1016/0003-9969(88)90123-9><PMid:3245794>

Martins M.T. 2016. Causas de morte e razões para eutanásia de gatos da Região Central do Rio Grande do Sul. Doctoral Dissertation, Universidade Federal de Santa Maria, Santa Maria. 60p.

Meinerz A.R.M., Antunes T.A., Souza L.L., Nascente P.S., Farias R.O., Cleff M.B., Gomes F.R., Nobre M.O., Reischak D., Schuch L.F.D. \& Meireles M.C.A. 2010. Frequência do vírus da leucemia felina (VLFe) em felinos domésticos (Feliscatus) semidomiciliados nos municípios de Pelotas e Rio Grande. Ciênc. Anim. Bras. 11(1):90-93.

Möstl K., Egberink H., Addie D., Frymus T., Boucraut-Baralon C., Truyen U., Hartmann K., Lutz H., Gruffydd-Jones T., Radford A.D., Lloret A., Pennisi M.G., Hosie M.J., Marsilio F., Thiry E., Belák S. \& Horzinek M.C. 2013. Prevention of infectious diseases in cat shelters. J. Feline Med. Surg. 15(7):546-554. <http://dx.doi.org/10.1177/1098612X13489210> <PMid:23813812>

Nisengard R.J., Kinder Haake S., Newman M.G. \& Miyasaki K.T. 2006. Microbial interactions with the host in periodontal diseases, p.228-250. In: Nisengard R.J., Kinder Haake S., Newman M.G. \& Miyasaki K.T. (Eds), Carranza's Clinical Periodontology. W.B. Saunders, St Louis.
O’Neill D.G., Church D.B., McGreevy P.B., Thomson P.C. \& Brodbelt D.C. 2014. Prevalence of disorders recorded in cats attending primary-care veterinary practices in England. Vet. J. 202(2):286-291. <http://dx.doi.org/10.1016/j. tvjl.2014.08.004> <PMid:25178688>

Pedersen N.C. \& Wastlhuber J.1991. Cattery design and management, p.393437. In: Pedersen N.C. (Ed), Feline Husbandry: diseases and management in the multiple-cat environment. American Veterinary Publications, Goleta.

Perry R. \& Tutt C. 2015. Periodontal disease in cats, back to basics: with an eye on the future. J. Feline Med. Surg. 17(1):45-65. <http://dx.doi. org/10.1177/1098612X14560099><PMid:25527493>

Poffo D., Almeida A.B.P.F., Nazakato L., Dutra V., Correa S.H.R., Mendonça A.J. \& Sousa V.R.F. 2017. Feline immunodeficiency virus (FIV), feline leukaemia virus (FeLV) and Leishmania sp. in domestic cats in the Midwest of Brazil. Pesq. Vet. Bras. 37(5):491-495. <http://dx.doi.org/10.1590/s0100736x2017000500011>

Quimby J.M., Elston T., Hawley J., Brewer M., Miller A. \& Lappin M.R. 2008. Evaluation of the association of Bartonella species, feline hepervirus 1, feline calicivirus, feline leukemia virus and feline immunodeficiency virus with chronic feline gengivostomatitis. J. Feline Med. Surg. 10(1):66-72. <http://dx.doi.org/10.1016/j.jfms.2007.05.007> <PMid:17766156>

Reiter A.M. \& Soltero-Rivera M.M. 2017. Oral and salivary gland disorders, p.3537-3551. In: Ettinger S.J., Feldman E.C. \& Côté E. (Eds), Textbook of Veterinary Internal Medicine. 8th ed. Elsevier, St Louis.

Rolim V.M., Pavarini S.P., Campos F.S., Pignone V., Faraco C., Muccillo M.S., Roehe P.M., Costa F.V. \& Driemeier D. 2016. Clinical, pathological, immunohistochemical and molecular characterization of feline chronic gingivostomatitis. J. Feline Med. Surg. 19(4):403-409. <http://dx.doi. org/10.1177/1098612X16628578> <PMid:26858258>

Santos L.D., Lucas R. \& Lallo M.A. 2013. Epidemiologia da imunodeficiência viral, leucemia viral e peritonite infecciosa em felinos procedentes de um hospital veterinário. Revta Acad., Ciênc. Agr. Amb. 11(2):161-168.

Sellon R.K. \& Hartmann K. 2012. Feline immunodeficiency virus infection, p.131-149. In: Greene C.E. (Ed), Infectious Diseases of the Dog and Cat. 4 th ed. Saunders Elsevier, St Louis.

Studer E. \& Stapley R.B. 1973. The role of dry foods in maintaining healthy teeth and gums in the cat. Vet. Med. Small Anim. Clin. 68(10):1124-1126. <PMid:4490506>

Teixeira B.M., Rajão D.S., Haddad J.P.A., Leite R.C. \& Reis J.K.P. 2007. Ocorrência do vírus da imunodeficiência felina e do vírus da leucemia felina em gatos domésticos mantidos em abrigos no município de Belo Horizonte. Arq. Bras. Med. Vet. Zootec. 59(4):939-942. <http://dx.doi.org/10.1590/ S0102-09352007000400019>

Tenorio A.P., Franti C.E., Madewell B.R. \& Pedersen N.C. 1991. Chronic oral infections of cats and their relationship to persistent oral carriage of feline calic-, immunodeficiency, or leukemia viruses. Vet. Immunol. Immunopathol. 29(1/2):1-14. <http://dx.doi.org/10.1016/0165-2427(91)90048-H> <PMid:1659031>

Watson A.D.J. 1994. Diet and periodontal disease in dogs and cats. Aust. Vet. J. 71(10):313-318. <http://dx.doi.org/10.1111/j.1751-0813.1994. tb00905.x><PMid:7848177>

Wiggs R.B. \& Lopprise H.B. 1997. Periodontology, p.186-231. In: Wiggs R.B. \& Lopprise H.B. (Eds), Veterinary Dentistry, Principals and Practice. Lippincott Raven, Philadelphia.

Winer J.N., Arzi B. \& Verstraete J.M. 2016. Therapeutic management of feline chronic gingivostomatitis: a systematic review of the literature. Front. Vet. Sci. 3(1):1-10.<http://dx.doi.org/10.3389/fvets.2016.00054> <PMid:27486584> 